\title{
METHOD OF WATER CONSUMERS SAFETY ANALYSIS AND ASSESSMENT
}

\author{
Dawid Szpak ${ }^{1, *}$ \\ ${ }^{1}$ Rzeszow University of Technology, Department of Water Supply and Sewage Systems, \\ Al. Powstańców Warszawy 6, 35-959 Rzeszów, Poland
}

\begin{abstract}
The subject of the publication is to present the method of water consumers safety analysis and assessment to implement the so-called Water Safety Plans (WSP), recommended by the World Health Organization (WHO) in Poland. The paper presents the method of water consumers safety analysis and assessment, which is based on failure mode and effects analysis (FMEA). The failure mode and effects analysis is widely used to analyse the reliability and safety of products and processes in technical systems. The procedure in the FMEA is based on the identification of potential undesirable events, assessment of effects and determining the causes of these events, assessment of frequency, the possibility of detection, estimating validity of the actions and estimating how to prevent undesirable events, re-examining and assessment of these events. The developed method of water consumers safety analysis and assessment is a complement and extension of recommended for WSP matrix methods, which according to the author's opinion is not sufficient for a proper analysis of undesirable events that may happen in collective water supply system (CWSS). The use of the FMEA method will allow for better identification of existing hazards and to determine the cause-effect relationships between them. Reliable access to drinking water is one of the basic conditions for the development of civilization.
\end{abstract}

\section{Introduction}

According to the act [1] collective water supply system (CWSS) is part of the critical infrastructure. This system is crucial for the functioning of society and the state. Wrong functioning of CWSS may be a threat to people health or lives. Therefore CWSS must be characterized by a high degree of reliability and safety $[2,3,4]$.

Water consumers safety is defined as the probability of avoiding threats associated with the consumption of poor quality water or lack of water supply. Water consumers safety is affected by a number of factors, which include, among others:

- the state of water supply infrastructure,

- the state of monitoring,

- exposure to internal and external threats,

- way to protect consumers against the consequences of undesirable events,

*Corresponding author: dsz@.prz.edu.pl 
specialized services for renovation and repair.

The need to constantly improve the level of water consumers safety has already been noticed by the World Health Organization (WHO) in the sixties of the twentieth century. Since then at first International Standards for Drinking-Water and later the Guidelines for Drinking Water Quality appeared regularly. Currently the fourth edition of the Guidelines for Drinking Water Quality issued in 2011 [5] is valid. One of the achievements of the Guidelines for Drinking Water Quality is the introduction of concept and assumptions for the so-called Water Safety Plans (WSP). The main purpose of the WSP is to ensure safe access to drinking water.

In 2009 the WHO published the Water safety plan manual: step-by-step risk management for drinking-water suppliers [6] which is a kind of instruction for water and sewage companies. This manual contains 11 stages of the development and implementation of the WSP. Currently in Poland there is no obligation to implement the WSP, while many Western European countries have entered this model in force, which contributed to improving the quality of functioning of CWSS and reducing the number of undesirable events. Against the countries of 'old' European Union we have in this regard a lot to do, so one should look for new opportunities that will allow for proper implementation of the WSP. The extension of the WSP is Water Cycle Safety Plan (WCSP) [7].

The main aim of this work is to present the methodology of analysis and assessment of water consumers safety for the purpose of implementing the WSP.

\section{Characteristics of undesirable events in CWSS}

The membership of CWSS to critical infrastructure requires from water companies to ensure the continuity of operation and a fast recovery of the performance in case of failure. There are three groups of factors that may cause undesirable events in CWSS: technical, human and environmental factors $[8,9]$.

Threats in water supply can occur at any stage of the production of water intended for human consumption: in water source, during treatment and storage, as well as in water distribution subsystem.

The main threats to water consumers safety are [6]:

- unfavourable weather conditions, e.g. floods, droughts,

- contamination of raw water which cannot be removed by conventional treatment process and the use of an alternative treatment technology is not possible,

- bad water and sewage management in the city/municipality,

- ineffective water treatment process,

- lack or reduction of the supply of electricity to the water treatment plant and zone pumping stations,

- secondary water contamination in water supply network or water tanks,

- failures of water supply network,

- intentional harmful action of the third parties,

- lack of adequate protection of key objects for the reliable CWSS functioning.

The frequency of undesirable events can be reduced by:

- diversification of water sources, extension of the monitoring system,

conducting regular inspections of the technical condition of the objects, maintaining efficient and suitably equipped emergency water and sewerage brigade, introduction of multibarrier system, development and implementation of WSP. 


\section{Materials and methods}

In the study we used the method of failure mode and effects analysis FMEA which is widely used to analyse the reliability and safety of products and processes in technical systems [10]. The standard [11] describes the FMEA method and provides guidelines for its use for different purposes.

The method of failure mode and effects analysis FMEA allows to analyse the product or process, to determine weak points and then to introduce improvements and new solutions to eliminate the source of undesirable events. For this reason, this method can be used to analyse water consumers safety in the implementation of WSP. The method of FMEA in CWSS was shown in Fig. 1 [12].

The assessment of water consumers safety is carried out based on risk priority number (RPN) according to the equation $[10,12-14]$ :

$$
R P N=S \cdot O \cdot D
$$

where:

$\mathrm{S}$ - Severity - point weight associated with the importance of undesirable event, $\mathrm{O}$ - Occurrence - point weight associated with the frequency of undesirable event, D - Detection - point weight associated with the ability to detect undesirable event.

The individual parameters are described by an integer from 1 to 10 , which is assumed on the basis of expert knowledge and experience of CWSS users. The result of the analysis is the RPN, taking values ranging from 1 to 1000. The higher RPN value, the lower level of water consumers safety. The input criteria for the individual parameters are assumed on the basis of the information contained in Tables 1,2 and $3[8,12,13]$. 


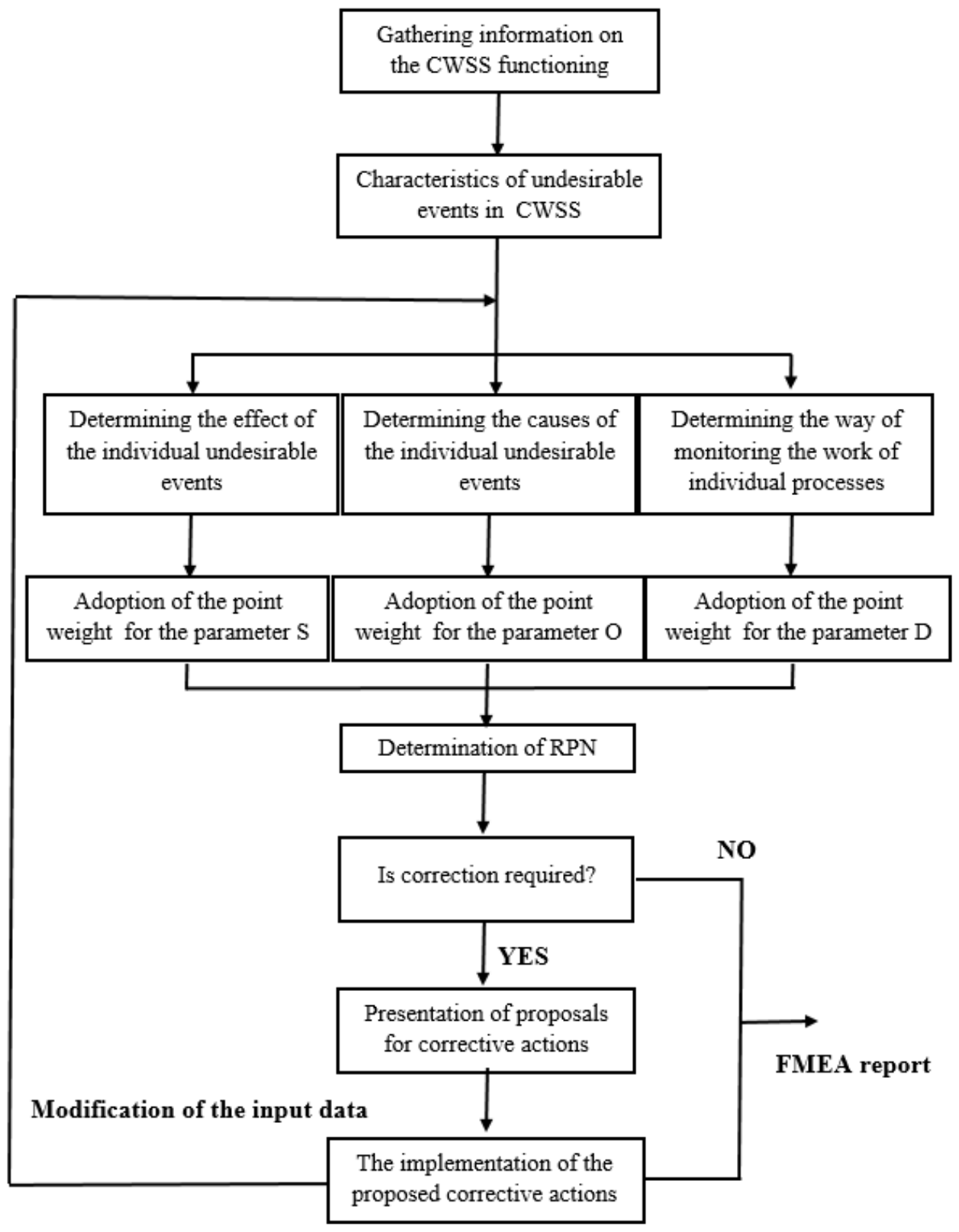

Fig. 1. The process of FMEA to assess water consumers safety. 
Table 1. Criteria and point weights for the parameter S.

\begin{tabular}{|c|c|c|}
\hline Severity & Description & Point weight \\
\hline remote & $\begin{array}{l}\text { There is no discernible effects, failure does not affect } \\
\text { functioning of the system, water is proper for human } \\
\text { consumption according to Act [15] }\end{array}$ & 1 \\
\hline \multirow{2}{*}{ low } & \multirow{2}{*}{$\begin{array}{c}\text { Disruptions in the operation of individual subsystems are } \\
\text { not felt by consumers, water is proper for human } \\
\text { consumption according to Act }[15]\end{array}$} & 2 \\
\hline & & 3 \\
\hline \multirow{3}{*}{ moderate } & \multirow{3}{*}{$\begin{array}{c}\text { Disruptions in the operation of individual subsystems } \\
\text { cause a high degree of water consumers dissatisfaction, } \\
\text { conditional suitability of water for consumption according } \\
\text { to Act [15] }\end{array}$} & 4 \\
\hline & & 5 \\
\hline & & 6 \\
\hline \multirow{2}{*}{ high } & \multirow{2}{*}{$\begin{array}{l}\text { The system does not work, there may be a threat to the } \\
\text { water consumers health, water is not proper for human } \\
\text { consumption according to Act [15] }\end{array}$} & 7 \\
\hline & & 8 \\
\hline \multirow{2}{*}{ very high } & \multirow{2}{*}{$\begin{array}{l}\text { Undesirable event is a threat to water consumers health } \\
\text { and lives, water is not proper for human consumption } \\
\text { according to Act [15] }\end{array}$} & 9 \\
\hline & & 10 \\
\hline
\end{tabular}

Table 2. Criteria and point weights for the parameter $\mathrm{O}$.

\begin{tabular}{|c|c|c|}
\hline Occurrence & $\begin{array}{c}\text { Frequency of } \\
\text { appearance }\end{array}$ & Point weight \\
\hline \multirow{2}{*}{ remote } & $<$ for 1000000 days & 1 \\
\hline \multirow{2}{*}{ moderate } & 1 for 20000 days & 2 \\
\cline { 2 - 3 } & 1 for 4000 days & 3 \\
\cline { 2 - 3 } & 1 for 1000 days & 4 \\
\cline { 2 - 3 } & 1 for 80 days & 5 \\
\hline \multirow{2}{*}{ high } & 1 for 40 days & 7 \\
\cline { 2 - 3 } & 1 for 20 days & 8 \\
\hline \multirow{2}{*}{ very high } & 1 for 8 days & 10 \\
\cline { 2 - 3 } & 1 for 2 days & 9 \\
\hline
\end{tabular}


Table 3. Criteria and point weights for the parameter D.

\begin{tabular}{|c|c|c|}
\hline Detection & Description & Point weight \\
\hline very high & $\begin{array}{l}\text { Complete monitoring, on-line equipment, potential } \\
\text { undesirable event almost certainly will be detected }\end{array}$ & 1 \\
\hline \multirow{2}{*}{ high } & \multirow{2}{*}{$\begin{array}{l}\text { Potential undesirable event is detected by automated } \\
\text { checks, which lead to error detection and protection from } \\
\text { its development }\end{array}$} & 2 \\
\hline & & 3 \\
\hline \multirow{3}{*}{ moderate } & \multirow{3}{*}{$\begin{array}{l}\text { Undesirable event will not be detected until the reduction in } \\
\text { the quality of water intended for human consumption or } \\
\text { performance loss }\end{array}$} & 4 \\
\hline & & 5 \\
\hline & & 6 \\
\hline \multirow{2}{*}{ low } & \multirow{2}{*}{ Undesirable event will not be detected until inspection } & 7 \\
\hline & & 8 \\
\hline \multirow{2}{*}{ remote } & \multirow{2}{*}{$\begin{array}{l}\text { There is no monitoring system, there is no chance to detect } \\
\text { potential undesirable event }\end{array}$} & 9 \\
\hline & & 10 \\
\hline
\end{tabular}

The safety assessment is based on comparison of the obtained value with the adopted scale. The paper proposes three levels of water consumers safety:

tolerable level of safety (TLS) - RPN $\leq 40$, in which as a result of the CWSS operation there is not any threat to water consumers lives or health,

controlled level of safety (CLS) $-40<\mathrm{RPN} \leq 100$, in which as a result of the CWSS operation, mainly due to the consumption of contaminated water, there may be a threat to consumers' health, but there are sufficient safety barriers, unacceptable level of safety (ULS) - RPN $>100$, beyond which as a result of the CWSS operation consumers are at risk of loss of health or lives.

\section{Results of analysis}

Table 4 shows a fragment of the FMEA analysis carried out for the CWSS located in the south-eastern Poland. Due to the limited volume of the publication the whole analysis of water consumers safety, covering tens of undesirable events, was not shown. Every undesirable event, its effects and causes is listed in the subsequent lines.

If the value of the RPN is higher than 100 (ULS), one must submit a proposal for remedial actions, indicate the person responsible for their implementation and the planned completion date. After the introduction of corrective actions the analysis must be made again, the value of RPN must be determined and the level of water consumers safety must be assessed. 
Table 4. A fragment of the FMEA analysis for the assessment of water consumers safety.

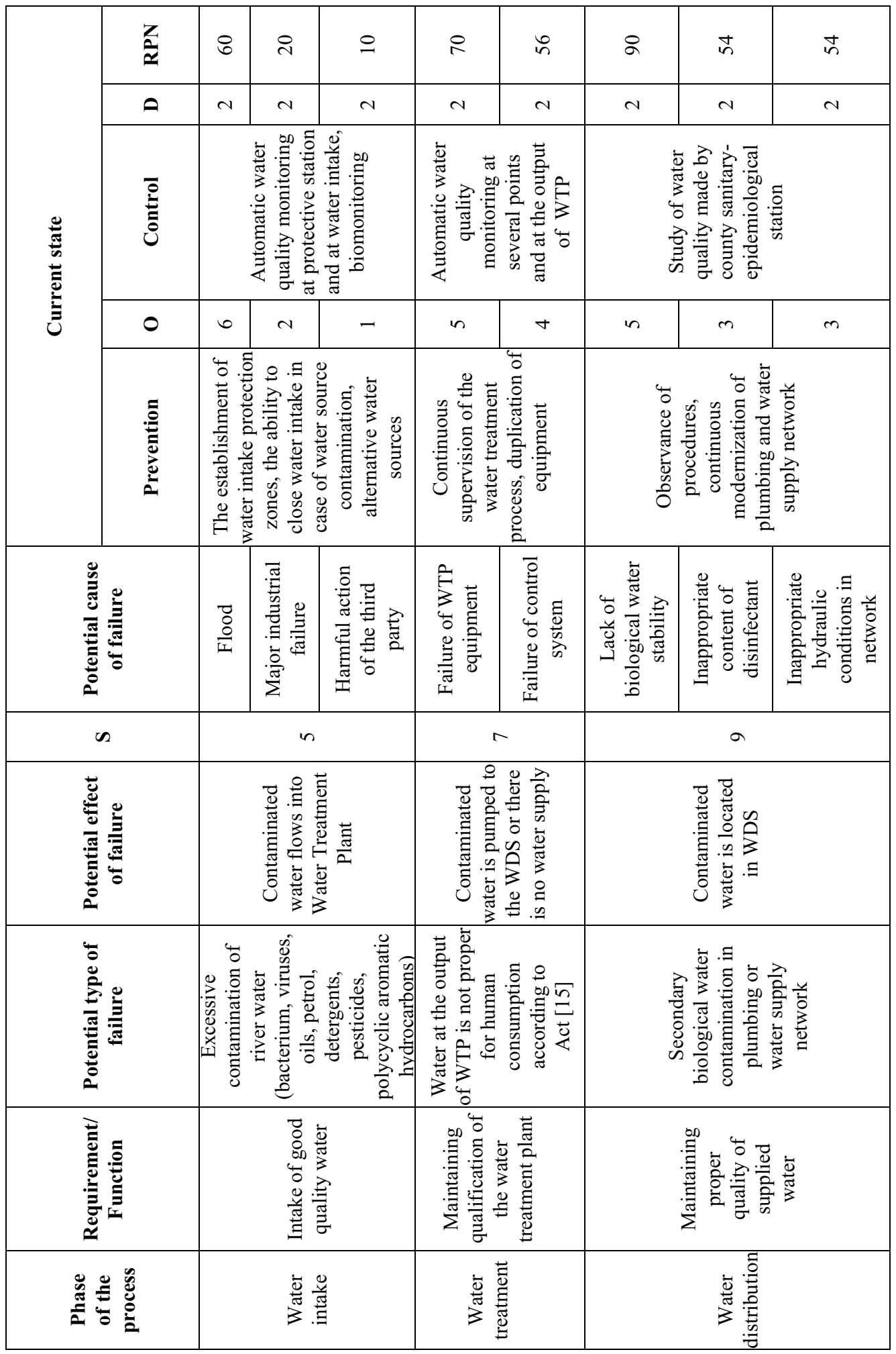




\section{Conclusions}

The FMEA method can be an important tool for analysis and assessment of water consumers safety for the purpose of implementing the WSP. It allows to identify the weak points of the system and determine actions which must be taken in order to raise the level of water consumers safety. The presented analysis showed that if undesirable events occur, water consumers safety is at an acceptable or controlled level.

Further studies on this topic should be aimed at seeking solutions allowing to develop the conventional FMEA method by, among others, introducing to the FMEA method the fuzzy set theory. It is also necessary to continue the discussion on the criteria values for the parameter RPN and the assessment of its value.

\section{References}

1. Ustawa z dnia 26 kwietnia 2007 r. o zarządzaniu kryzysowym (Dz.U. 2007 Nr 89 poz. 590) z późniejszymi zmianami

2. K. Boryczko., B. Tchórzewska-Cieślak: Environment Protection Engineering, 40(4), 77-92 (2014)

3. B. Tchórzewska-Cieślak, J. Rak: Method of identification of operational states of water supply system. ENVIRONMENTAL ENGINEERING III, Ed. Pawlowski, L; Dudzinska, MR; Pawlowski, A. Taylor \& Francis Group, 521-526 (2010)

4. K. Pietrucha-Urbanik: Engineering Failure Analysis, 57, 137-142 (2015)

5. Guidelines for Drinking-water Quality. Fourth Edition. WHO, Geneva (2011)

6. Water safety plan manual: step-by-step risk management for drinking-water suppliers. WHO, Geneva (2009)

7. M.C. Almeida, P. Vieira, P. Smeets: Water cycle safety plan framework. Final. Prepared 2013.025 (2013)

8. B. Tchórzewska - Cieślak, D. Szpak: Ochrona Środowiska , 37(3), $43-47$ (2015)

9. B. Tchórzewska-Cieślak, K. Boryczko, I. Piegdoń: Possibilictic risk analysis of failure in water supply network. Safety and Reliability: Safety and Applications, Taylor \& Francis Group, 1473-1480, London (2015)

10. DH. Stamatis : Failure mode and effect analysis-FMEA from theory to execution. New York: ASQC Quality Press (1995)

11. PN-EN 60812:2009. Analysis techniques for system reliability: procedure for failure mode and effects analysis (FMEA)

12. A. Pillay, J. Wang: Reliability Engineering and System Safety, 79, 69-85 (2003)

13. Y.M. Wang, K.S. Chin, G.K.K. Poon, J.B. Yang: Expert Systems with Applications, 36, 1195-1207 (2009)

14. M. Kumru, P.Y. Kumru: Applied Soft Computing, 13, 721-733 (2013)

15. Rozporządzenie Ministra Zdrowia z dnia 13 listopada 2015 r. w sprawie jakości wody przeznaczonej do spożycia przez ludzi (Dz.U. 2015 poz. 1989) 